\title{
Mobile In-App Advertising for Tourism: A Case Study
}

\author{
Tek Yong Lim, Teck Lun Tan, and Geoffrey Emeka Jnr Nwonwu \\ Faculty of Computing and Informatics, Multimedia University, \\ Jalan Multimedia, 63100 Cyberjaya, Selangor, Malaysia \\ tylim@mmu.edu.my, alecteck@gmail.com, mekkzy@yahoo.com
}

\begin{abstract}
A successful tourism advertisement can attract tourists to a certain country. This paper explored the effective ways of incorporating ads in mobile app for tourism industry. My Travel Malaysia was selected as a case study. A mobile advertising guideline was used for creation of mobile in-app banner ad. A mobile app prototype was developed and embedded with four different ads. A usability testing was carried out with ten participants and all were asked to find a particular hotel room rate. The results revealed that participants were able to recall images banner ad compare to text banner ad but they were also more likely to perceive large image banner ad as app content. However, all participants did not click on these banner ads because not relevant to their tasks.
\end{abstract}

Keywords: In-App Advertising, Mobile Tourism, Usability Testing.

\section{Introduction}

Tourism is mainly giving services to travelers such as transportation, hospitality, entertainment venues, travel agencies, tour operator and other related services. In short, tourism is about selling dreams to people and promotion such as advertising plays an important role in tourism. Previous studies showed that a successful advertisement could attract tourists to a certain country [1]. In 2011, travel and tourism industries spent \$2.4 billion and were ranked as the third spenders on Google AdWords [2]. The tops five companies that spent million on Google advertising were Booking.com, Expedia, Kayak, Marriott and Priceline.com.

[3] estimated that there were 6.8 billion mobile subscriptions in 2013 and more than half of subscribers in the Asia-Pacific region. A recent study by [4] indicated that $51 \%$ of smart phone owners accessed travel information on their devices while planning a trip or traveling. This included air travel related activity (e.g. check airfare price) and hotel related activity (e.g. look up hotel direction). This is an opportunity for advertisers to reach out their potential mobile travelers. There were many advertising strategies employed on mobile device. For example, ads were displayed in mobile app, mobile web, mobile video, text messaging, and multimedia messaging. [5] predicted that mobile advertisement would generate $\$ 24.5$ billion for app developers in 2016. Thus, this paper explored the effective ways of incorporating ads in mobile app for tourism industries. 


\section{Literature Review}

There are various definitions of advertising. [6] suggested that advertising is defined as a communication designed to entice an audience to take some action, either instantly or in the near future. The advertisement is usually paid from an identifiable source and can be conveyed through print, electronics and other methods.

Newspaper and magazine are considered the common venues for advertisers. Unlike the traditional advertising, online advertisers were able to display interactive and more personalized ad content for each individual [7]. Web developers would specify an ad unit (usually a rectangle space allocated for displaying ads) in their web page. Although the online ad goals were to build a product image and stimulate direct purchase, but previous studies revealed that many users rated negatively on their experience with online ads. The following were examples of bad ad design element: pop-up window, taking long time to load, attempt to deceive user into clicking on it, disappearance of close button, doesn't tell its purpose, content being shifted, and others [8]. In addition, [9] found that ad banners also decreased user search performance. Thus, a guideline was provided to design a good online ad. The ad should inform what will happen if user click on it, relate with user current online task, identify itself as advertisement, tell the advertising purpose, and supply additional information without leaving the current page [8].

In mobile setting, developers need to understand the user behavior and hardware limitation. Mobile users would use their mobile device for two main tasks, namely to save time and to fill time [10]. In time saving situation, user would search quick information on the fly and then return to what they were doing. In time filling situation, user would engage with entertaining app to fill short moments in the day. Besides that, developers also need to support wide spectrum of different mobile devices on the market that varied in term of user interfaces, processor capabilities, storage size and display resolution. Therefore, [11] established a standard guideline on mobile advertising. This guideline proposed different ways displaying ads in mobile app such as in-app display advertising unit, integrated ad, branded mobile app, and sponsored mobile app. There were relatively few studies on user experience of mobile in-app advertising and how these mobile ads affect the users.

\section{Design of Mobile In-App Banner Ad}

There is a need to design effective mobile in-app banner ad for promoting Malaysia because Malaysia became the ninth most visited country in term of the number of international travelers in year 2011. My Travel Malaysia is a free mobile app available in iTunes store and one of the Top 10 Malaysia Travel Apps. Thus, this app is selected as a case study. Mobile travelers can search specific destination by typing in the location name (see Figure 1). If mobile travelers are unfamiliar with the local places, they can still find nearby attractions and hotels by using their current mobile global positioning system (GPS). Mobile travelers can save an attraction or hotel by adding it to favorites and share it with friends via email. 

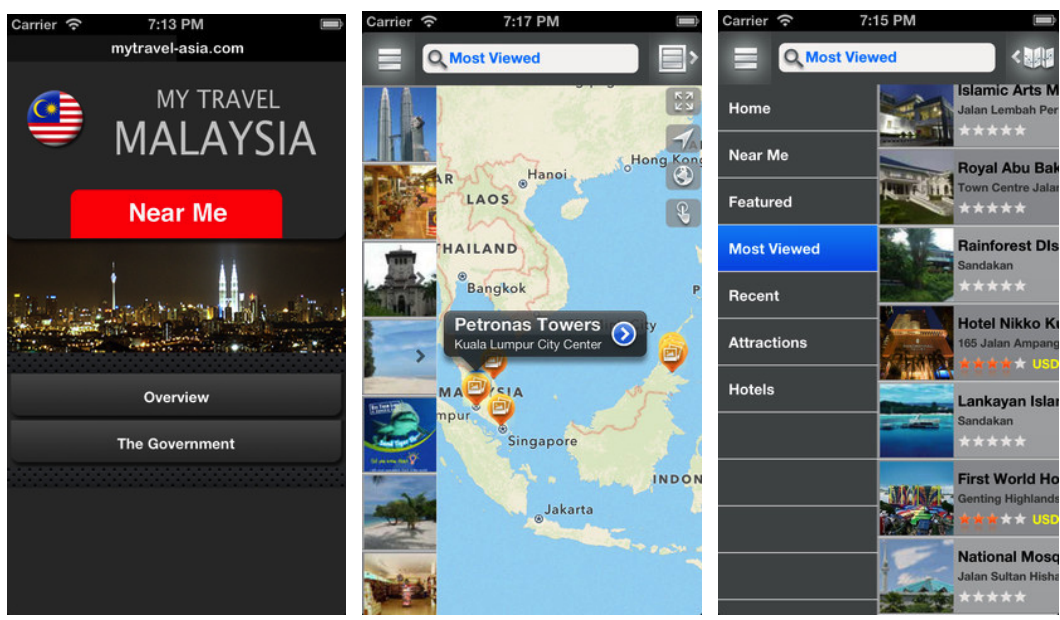

Fig. 1. Screenshots of My Travel Malaysia app

Mobile advertising guidelines by [11] is used for designing mobile in-app banner. Mobile in-app banner ad is defined as a color image ad unit appears within a mobile application. This banner ad can be display in the form of a still image, text or both. This banner ad can be placed anywhere within the mobile app such as main menu and content page. Mobile user can click on the banner ad. A low fidelity prototype based on My Travel Malaysia app was developed. This mobile app prototype was embedded with four different banner ads (Ad 1, Ad 2, Ad 3 and Ad 4). Three banner ads were still images in JPG format but with different heights and widths (see Table 1). The images were taken from Malaysia Airline System and Sabah Tourism Board. The fourth banner ad was a white text tagline with black background. Ad 1 was placed below "Overview" content page. Ad 2 and Ad 4 were placed below "Main menu" page. Ad 3 was placed within "Hotels" listing. All banner ads were visible on screen and user would receive additional information from advertiser when clicking on the ads. User can return to the previous page in the app prototype by clicking back button.

\section{$4 \quad$ Usability Testing}

The purpose of this usability testing was twofold: (1) to assess user memory for mobile in-app banner ad and (2) to find out why user ignore or interact with the banner ad. Ten participants ( 5 males and 5 females) volunteered to take part in this testing and all gave informed consent. Seven participants were Malaysian and the remaining were foreigners. All participants had computer experience and had used mobile travel app.

The usability testing was conducted in a controlled setting. First, each participant was asked to fill out a short survey. Then, the participant was given a brief introduction to mobile app prototype and was asked to find the room rate of Glenmarie Hotel, Selangor using the app prototype. Participants were encouraged to think aloud while 
performing the task. After the participant completed his/her task, each participant was interviewed using the following questions: (1) How many banner ads did you noticed? (2) Do you think you will click on the banner ads? If not, why?

Table 1. Design of Mobile In-App Banner Ad Units

\begin{tabular}{|c|c|c|}
\hline Ad Design & $\begin{array}{l}\text { Technical } \\
\text { Specifications }\end{array}$ & Example (approx. dimension) \\
\hline $\begin{array}{l}\text { Ad } 1 \text { (MAS, Fly } \\
\text { Me There) }\end{array}$ & $\begin{array}{l}\text { XX-Large Image } \\
\text { Banner } \\
320 \text { x } 320 \text { pixels } \\
\text { JPEG still image }\end{array}$ & 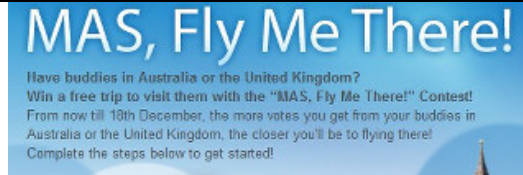 \\
\hline $\begin{array}{l}\text { Ad } 2 \text { (Sabah Tour- } \\
\text { ism Board) }\end{array}$ & $\begin{array}{l}\text { X-Large Image } \\
\text { Banner } \\
300 \times 75 \text { pixels } \\
\text { JPEG still image }\end{array}$ & \\
\hline $\begin{array}{l}\text { Ad } 3 \text { (Super Sales } \\
\text { Malaysia) }\end{array}$ & $\begin{array}{l}\text { Large Image Banner } \\
216 \text { x } 36 \text { pixels } \\
\text { JPEG still image }\end{array}$ & 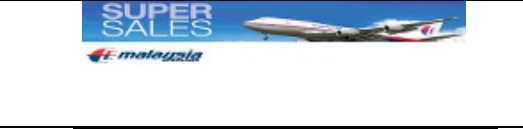 \\
\hline $\begin{array}{l}\text { Ad } 4 \text { (Sipadan } \\
\text { Travel Package) }\end{array}$ & $\begin{array}{l}\text { Text Tagline } \\
22 \text { characters }\end{array}$ & Sipadan Travel Package \\
\hline
\end{tabular}

The findings revealed that all participants completed the task successfully. All participants were able to recall the Ad 2 due to its prominent colorful visual and location on main page. Eight participants recalled the Ad 3. However, only one participant recalled the Ad 4 because most participants ignored the bottom part of main page. There is only one participant able to recall the Ad 1 because most participants thought the large image was part of the app content instead of banner ad. However, all participants did not click on any of these mobile in-app banner ads because these banner ads were not relevant to the task given.

\section{Discussion and Conclusion}

The results revealed that participants experienced text ad blindness in mobile setting because they tend to miss information in text banner ad compare to image banner ad. This is especially true when participants are searching for specific information [12]. 
On the other hand, they were also more likely to perceive xx-large image banner ad as app content. This is considered as unethical because the ad can mislead participants and resulted negative impact on business [13]. Having an image banner ad in mobile app can be a double-edged sword.

In conclusion, this paper showed that the current mobile advertising guideline was good for ensuring advertisements being display effectively across different mobile devices. However, [14] suggested that advertisements only work if an ad fit with the user's goal. Future work will concentrate on matching relevant banner ad to in-app content and evaluate the banner ad effectiveness based on user click.

\section{References}

1. Brida, J.G., Schubert, S.F.: The Economic Effects of Advertising on Tourism Demand. Economics Bulletin 6(45), 1-16 (2008)

2. Kim, L.: What Industries Contributed to Google's $\$ 37.9$ Billion in 2011 Revenues, http: / /www. wordstream.com/blog/ws/2012/01/23/google-revenues

3. International Telecommunication Union The World in 2013 ICT Facts and Figures, http://www.itu.int/ITU-D/ict/facts/material/ ICTFactsFigures2013.pdf

4. Radwanick, S.: Smart Travel: Majority of Smartphone Owners Now Access Travel Information on their Devices, http: / / www. comscore.com/Insights / Press_Releases/2012/4/Majority_of_Smartphone_Owners_Now_ Access_Travel_Information_on_their_Devices

5. Baghdassarian, S., Frank, A.: Forecast: Mobile Advertising, Worldwide (2009-2016), http: / / www . gartner. com/resId=2247015

6. Richards, J.I., Curran, C.M.: Oracles on "Advertising": Searching for a Definition. Journal of Advertising 31(2), 63-77 (2002)

7. Park, T., Shenoy, R., Salvendy, G.: Effective Advertising on Mobile Phones: A Literature Review and Presentation of Results from 53 Case Studies. Behaviour and Information Technology 27(5), 355-373 (2008)

8. Nielsen, J.: The Most Hated Advertising Techniques, http: / /www.nngroup. com/ articles/most-hated-advertising-techniques /

9. Burke, M., Hornof, A., Nilsen, E., Gorman, N.: High-Cost Banner Blindness: Ads Increase Perceived Workload, Hinder Visual Search, and Are Forgotten. ACM Transactions on Computer-Human Interaction 12(4), 423-445 (2005)

10. Interactive Advertising Bureau: A Mobile Advertising Overview, http://www.iab.net/media/file/moble_platform_status_report.pdf

11. Mobile Marketing Association: Mobile Advertising Guidelines, Version 5.0, http: / / www.mmaglobal.com/files/mobileadvertising.pdf

12. Owens, J.W., Chaparro, B.S., Palmer, E.M.: Text Advertising Blindness: The New Banner Blindness? Journal of Usability Studies 6(3), 172-197 (2011)

13. Spizziri, M.: Ethical Issues in Online Advertising: Rules for Online Ads, http: //advertising.about.com/od/onlineadvertising/ a/guestethicalads.htm

14. Nielsen, J., Norman, D.: Making Web Advertisements Work, http: //www.nngroup.com/articles/ making-web-advertisements-work/ 